\title{
Konservatoriji v procesu profesionalizacije in specializacije glasbenega dela
}

\author{
Jernej Weiss \\ Univerza v Ljubljani / Univerza v Mariboru
}

Namen pričujoče znanstvene monografije je razmislek o idejnih, organizacijskih in vsebinskih vidikih glasbenega izobraževanja v srednjeevropskem in južnoslovanskem glasbenem prostoru $\mathrm{v}$ luči splošnih in narodnostno specifičnih razvojnih glasbenih tokov po letu 1918, s posebnim poudarkom na pretoku znanja in nosilcev javnega glasbenega izobraževanja. Sicer pa je v središču raziskovalnega zanimanja četrte monografije zbirke Studia musicologica Labacensia $\mathrm{z}$ naslovom Konservatoriji: profesionalizacija in specializacija glasbenega dela: Ob stoletnici ustanovitve ljubljanskega Konservatorija in osemdesetletnici Glasbene akademije v Ljubljani delovanje leta 1919 ustanovljenega ljubljanskega konservatorija in njegove dve desetletji mlajše naslednice Glasbene akademije ter podobnih glasbenih ustanov v Evropi pred in med obema vojnama.

Prispevki znanstvene monografije so razdeljeni v tri tematske sklope. Prvi (Delovanje konservatorijev pred in med obema vojnama $v$ evropskem glasbenem prostoru) proučuje nekatere najpomembnejše mejnike v razvoju konservatorijev pred in po prvi svetovni vojni. V prvi vrsti zanimanje posveča razvoju visokega glasbenega šolstva v luči družbenih sprememb med obema svetovnima vojnama, proučuje stopnje institucionalizacije in državnega nadzora ter pozornost namenja pedagoškim pristopom in koncertnemu repertoarju konservatorijskih produkcij.

Drugi sklop (Razvoj višjega in visokega glasbenega šolstva med obema svetovnima vojnama na Slovenskem) poseben poudarek namenja nosilcem 
višjega in visokega glasbenega šolstva na Slovenskem ter njihovi vlogi pri razvoju posameznih predmetnih področij, pedagoškim konceptom in pristopom k poučevanju, kot tudi institucionalnim spremembam KonservatorijGlasbena akademija.

Tretji sklop (Visoko glasbeno šolstvo po letu 1918 v južnoslovanskem glasbenem prostoru) pa svojo pozornost posveča povezanosti oz. razlikam "novega« južnoslovanskega visokošolskega prostora ter raziskavam metodik poučevanja posameznih glasbenih predmetov.

Konec leta 1918 je pomenil eno od ključnih prelomnic evropske novejše zgodovine. Zaznamovali so ga politično preoblikovanje Evrope in nastanek vrste novih držav. Tudi za Slovence je imelo omenjeno obdobje večkratni zgodovinski pomen. Prelom s starodavno monarhijo v simbolnem smislu ponazarjajo dogodki ob zadnjem koncertu t. i. "nemške« Filharmonične družbe v Ljubljani 25. oktobra 1918 v Tonhalle, danes stavbi Slovenske filharmonije. Tri dni kasneje je namreč v sosednjem Deželnem dvorcu, kjer danes domuje Univerza v Ljubljani, potekala ustavodanja skupščina Narodnega sveta, ki naj bi Slovence popeljal v nove čase. 29. oktobra 1918 pa so se nato Slovenci z veliko manifestacijo na Kongresnem trgu po dobrih 600 letih poslovili od razpadle monarhije in skupaj s Hrvati in Srbi oblikovali novo državo južnih Slovanov, ki je bila 1. decembra tega leta preoblikovana v Kraljevino Srbov, Hrvatov in Slovencev.

Konec vezi s Habsburžani ter drugačno geografsko, politično, gospodarsko, kulturno in jezikovno bivanjsko okolje so pomembno vplivali tudi na organizacijo in delovanje slovenskih kulturnih ter znanstvenih ustanov. Spremenjene razmere po koncu prve svetovne vojne so vsekakor pospešile institucionalizacijo kulturnih in znanstvenih interesov na narodni osnovi. V zgolj kratkem času po koncu vélike vojne je slovenska prestolnica $\mathrm{z}$ univerzo, državnim gledališčem in konservatorijem dobila vrsto dolgo pričakovanih poklicnih znanstvenih oziroma kulturnih ustanov osrednjega nacionalnega pomena. Te so pomenile odločilen korak Slovencev v krog kulturno razvitih nacij.

Septembra 2019 je tako minilo sto let od začetka delovanja Konservatorija Glasbene matice v Ljubljani. Za slovensko glasbeno kulturo ima ustanovitev konservatorija, ki je bil leta 1926 podržavljen in leta 1939 reorganiziran v Glasbeno akademijo, poseben pomen. Ustanovitev je bila sad dolgoletnega prizadevanja Slovencev za dvig ravni glasbenega izobraževanja v narodnostnem središču - Ljubljani. 
Pobudo za uresničitev načrta je po vojni obudil tedaj gotovo eden najvplivnejših glasbenikov na Slovenskem Matej Hubad, sicer koncertni vodja ljubljanske Glasbene matice in kasnejši ravnatelj konservatorija. Ocenjeval je, da vpis v šolo Glasbene matice in strokovni kader že izpolnjujeta pogoje za dvig šole na višjo stopnjo in o tem začel dialog z Deželno vlado. Zastavil si je velikopotezen načrt, da postane konservatorij zbirališče vseh Jugoslovanov. "Konservatorij naj bo kulturno svetišče glasbene, operne in dramatične umetnosti«, je zapisal Hubad in ga ocenil kot pogoj, da se jugoslovanska kultura postavi enakopravno nasproti drugim, da bo »mogla tekmovati s svetovnimi kulturnimi narodi. "' Glasbeno šolanje naj bi tako dvignili na višjo raven, ki bi zmogla zadostiti potrebam razvoja glasbene ustvarjalnosti v novi državi. ${ }^{2}$ Vsekakor je imela prav Glasbena matica v začetnih letih obstoja konservatorija osrednjo vlogo, saj je tako finančno kot personalno izdatno podprla njegovo delovanje.

Namen glasbenega izobraževanja na ljubljanskem konservatoriju je bil sicer enak kot drugod po Evropi: zagotoviti potrebne strokovne temelje za poklicno glasbeno delo, primerno pevsko, instrumentalno in teoretično izobrazbo glasbenim učiteljem, koncertnim ter opernim pevcem, opernim in koncertnim dirigentom ter instrumentalistom za igranje v orkestru. Njegovo delovanje je po prvi vojni pospešilo profesionalizacijo in specializacijo glasbenega življenja Slovencev. Tako je bil konservatorij zasnovan po vzoru praškega in dunajskega, zgled njegovemu vodstvu pa je bilo tudi delovanje zagrebškega konservatorija. Slednji je bil kot prvi med južnoslovanskimi narodi ustanovljen tri leta poprej.

Zaradi velikega interesa gojencev je imela direkcija že na samem začetku velike težave s pomanjkanjem ustrezno izobraženih pedagogov. Za člane učiteljskega zbora so bili imenovani ugledni skladatelji in poustvarjalci, ki so svoje znanje poprej pridobili na nekaterih najpomembnejših izobraževalnih ustanovah v tujini. Med njimi: Janko Ravnik, Josip Vedral in Jan Šlais (vsi trije absolventi Državnega konservatorija v Pragi), ki so se jim kasneje pridružili še Julij Betetto, Dana Kobler, Karel Jeraj, Lucijan Marija Škerjanc in drugi. Kljub težavnim začetkom jim je z veliko entuziazma uspelo vzgojiti prvo generacijo doma izobraženih slovenskih glasbenikov, ki so nato zasedli nekatera najbolj odgovorna glasbena mesta v državi. Študij na ljubljanskem konservatoriju so med prvimi zaključili: violinist Karlo

1 Matej Hubad, »Jugoslovanski konservatorij Glasbene Matice v Ljubljani«. Učiteljski tovariš 59, št. 35 (27. avgust 1919): 1.

2 Ibid. 
Rupel, pevska pedagoginja Angela Trost, skladatelji Pavel Šivic, Marijan Lipovšek, Franc Šturm in številni drugi vrhunski umetniki, med katerimi najdemo tudi Antona Dermoto, kasnejšega dolgoletnega prvaka dunajske državne opere.

Z njihovimi prizadevanji je že v 20 . letih vse bolj rastla zavest, da je potrebno konservatorij modernizirati, glasbeno izobraževanje pa razširiti še na mojstrsko stopnjo ter v program vpeljati tudi nekatere znanstvene študije. Tako si je eden prvih pedagogov konservatorija, utemeljitelj slovenske muzikologije Josip Mantuani že leta 1922 prizadeval za ustanovitev muzikološke stolice, vendar se njegovi načrti niso uresničili. Sicer pa je vodstvo konservatorija po podržavljenju vse bolj intenzivno lobiralo, da bi ustanova dobila status visoke šole, kar je bilo po dolgotrajnih pogajanjih z najvišjimi oblastmi v Beogradu naposled realizirano leta $1939 \mathrm{z}$ ustanovitvijo Glasbene akademije $v$ Ljubljani.

Vsekakor pa je bil na višji stopnji glasbenega izobraževanja že z ustanovitvijo konservatorija dosežen prvi pomembnejši stik s sodobnimi pedagoškimi dosežki v tujini. V skromnih personalnih, finančnih in materialnih pogojih delovanja je konservatorij dosegal pomembne, na nekaterih področjih (denimo pianističnem $\mathrm{v}$ razredu Janka Ravnika, violinskem Jana Šlaisa ali solopevskem Julija Betetta) zavidanja vredne uspehe. Vse do druge svetovne vojne je bil tako edina umetniška izobraževalna ustanova na Slovenskem, ki je izdajala državno veljavne diplome, saj so bile ideje o ustanovitvi sorodne šole za gledališko umetnost in likovno ustvarjalnost uresničene šele po drugi svetovni vojni. $Z$ njegovim obstojem so bili pri nas postavljeni strokovni temelji za poklicno glasbeno delo, slovenska glasbena kultura pa je dobila nove možnosti ter spodbude, ki so se kazale tako na področju glasbene reprodukcije in produkcije kot tudi v razvoju metodik poučevanja posameznih glasbenih predmetov. 